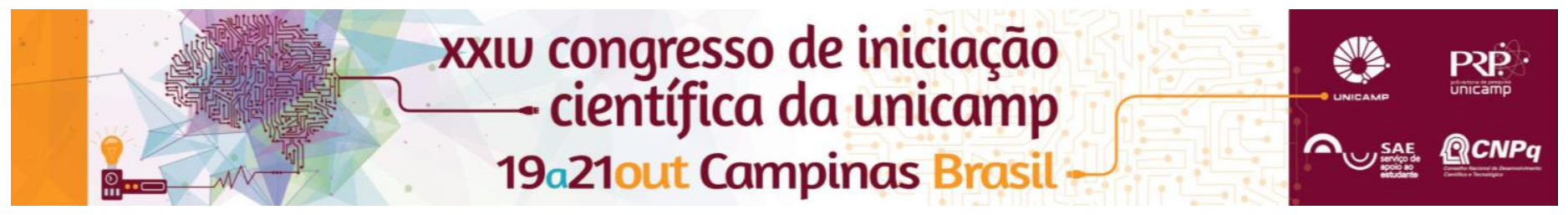

\title{
Impacto da desinfecção de efluentes sanitários nos atributos biológicos e químicos do solo
}

\author{
Lucas Agnelo* (IC), Noely B. Silva (PG), Fernando P. Candello (Biólogo PAEPE), Jerusa Schneider (PQ).
}

\section{Resumo}

O ácido peracético e o hipoclorito de cálcio são desinfetantes alternativos que podem ser utilizados no tratamento de efluentes. Desse modo, o objetivo deste trabalho foi avaliar alterações químicas e microbiológicas no solo após a utilização de determinadas concentrações desses desinfetantes, visando o reúso do efluente tratado e desinfetado na agricultura. Para isso foram realizados, primeiramente, ensaios de fitotoxicidade com sementes de alface, a fim de determinar quais doses causam efeitos fitóxicos à germinação. Por meio de tais ensaios, escolheu-se as doses 3 e $25 \mathrm{mg} / \mathrm{L}$ de ácido peracético e hipoclorito de cálcio, respectivamente, para serem submetidas à respirometria de Bartha e então observar os possíveis efeitos na atividade microbriana do solo. Contudo, ambas as doses não causaram efeitos tóxicos à microbiota e verificou-se que a concentração de hipoclorito de cálcio de $25 \mathrm{mg} / \mathrm{L}$ possui um maior potencial de biodegradabilidade.

Palavras-chave: Desinfecção, Tratamento de esgoto, Reúso.

\section{Introdução}

O tratamento e desinfecção de efluentes são realizados para remover ou inativar microrganismos patogênicos. Atualmente, a desinfecção é feita em sua maioria por cloração, no entanto, esse processo pode acarretar a formação de subprodutos perigosos à saúde humana e ao meio ambiente 1 . Neste contexto, o objetivo deste trabalho foi determinar doses do efluente desinfetado com ácido peracético e hipoclorito de cálcio a serem aplicadas no solo e observar as possíveis alterações nas principais propriedades químicas e microbiológicas, incentivando a prática de reúso do efluente na agricultura.

\section{Resultados e Discussão}

Para determinar as concentrações dos desinfetantes a serem estudadas, primeiramente foi realizado um ensaio de fitotoxicidade com sementes de alface (Lactuca sativa). O princípio do ensaio consiste em expor sementes a amostras ambientais, diluídas ou não, por um período de 120 horas em ausência de luz e temperatura controlada $\left(25^{\circ} \mathrm{C} \pm 1\right)$. As doses testadas foram nomeadas T1, T2, T3, T4, T5 e T6 correspondendo respectivamente às concentrações: 0,5 ; 0,$75 ; 1,5 ; 3 ; 5$ e $10 \mathrm{mg} / \mathrm{L}$ de ácido peracético e $6,12,18$, 25,32 e $64 \mathrm{mg} / \mathrm{L}$ de hipoclorito de cálcio.

A partir desse teste, obteve-se o Índice de Crescimento Relativo (ICR) das radículas das sementes germinadas, sendo possível observar a inibição do comprimento da raiz $($ ICR $<0,8)$ a partir de T5 em ambos os tratamentos.

Com base nestes resultados, foram realizados ensaios de Respirometria de Bartha com solo coletado próximo ao Laboratório de Protótipos da Faculdade de Engenharia Civil, Arquitetura e Urbanismo da UNICAMP, utilizando as concentrações 3 e 25mg/L (T4) de ácido peracético e hipoclorito de cálcio, respectivamente. Tal ensaio consiste na determinação da biodegradação de resíduos misturados ao solo pela atuação de microrganismos presentes. $O$ ensaio com ácido peracético foi incubado por 15 dias e com hipoclorito de cálcio por 57 dias, ambos a $28^{\circ} \mathrm{C} \pm 2$.

Nota-se na Figura 1 que a produção efetiva de $\mathrm{CO}_{2}$, aquela em que se desconta a produção de $\mathrm{CO}_{2}$ do controle, é muito maior no tratamento com hipoclorito de cálcio, indicando um maior potencial de biodegradação do desinfetante. No entanto, o fato deste ensaio ter levado mais tempo mostra que a sua estabilização é mais demorada do que a do ácido peracético. Também é importante ressaltar que não foi observado efeito tóxico em nenhum dos tratamentos, já que em ambos foram gerados uma curva de produção efetiva crescente.

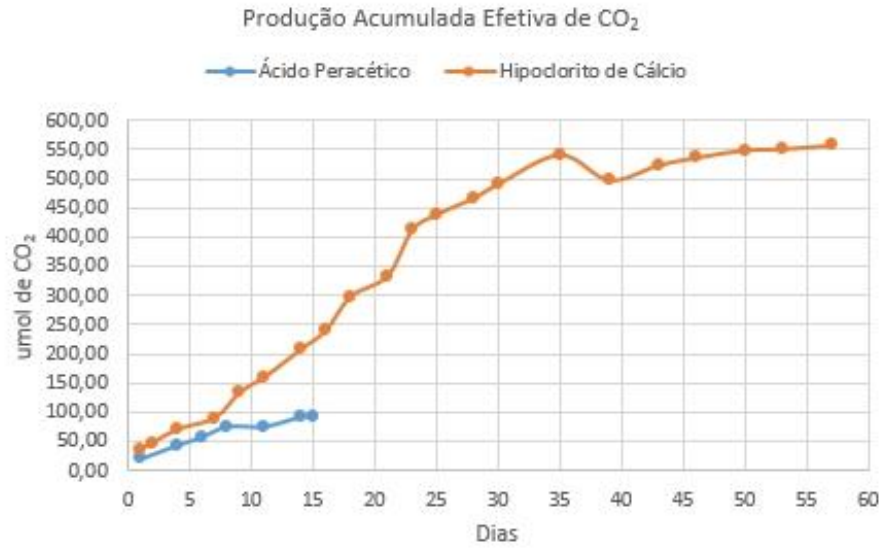

Figura 1. Produção média acumulada efetiva de $\mathrm{CO}_{2}$ nos respirômetros.

\section{Conclusões}

Conclui-se que há efeitos tóxicos às plantas a partir das concentrações T5 para ambos os desinfetantes e que dentre as doses submetidas à respirometria de Bartha, a concentração de $25 \mathrm{mg} / \mathrm{L}$ de hipoclorito de cálcio apresenta maior potencial de biodegradabilidade em relação ao ácido peracético $(3 \mathrm{mg} / \mathrm{L})$, sendo possível que esta cause menor impacto no solo.

\section{Agradecimentos}

Ao CNPQ por fomentar esta pesquisa, a Jerusa Schneider pela orientação, a Noely B. Silva e Fernando P. Candello pela colaboração no desenvolvimento das atividades.

GONÇALVES, R. F. Desinfecção de efluentes sanitários, remoção de organismos patógenos e substâncias nocivas. Aplicações para fins produtivos como agricultura, aqüicultura e hidroponia. Programa de Pesquisas em Saneamento Básico - PROSAB - Edital 03, Departamento de Saneamento Ambiental da UFES, 2003. 